\title{
СООТНОШЕНИЕ ПРИРОДНЫХ И АНТРОПОГЕННЫХ ФАКТОРОВ В РАЗВИТИИ ЛАНДШАФТОВ БАССЕЙНА РЕКИ РАЗДОЛЬНАЯ, ПРИМОРЬЕ
}

\author{
(C) 2020 г. Н. Г. Разжигаева ${ }^{a, *, * *}$, Л. А. Ганзей ${ }^{a}$, Т. А. Гребенникова ${ }^{a}$, Т. В. Корнюшенко \\ К. С. Ганзей ${ }^{a}$, Е. П. Кудрявцева ${ }^{a}$, И. В. Гридасова ${ }^{b}$, Н. А. Клюев ${ }^{b}$, С. Д. Прокопец ${ }^{b}$ \\ ${ }^{a}$ ФГБУН Тихоокеанский институт географии ДВО РАН, Владивосток, Россия \\ ${ }^{b}$ ФГБУН Институт истории, археологии и этнографии народов Дальнего Востока ДВО РАН, Владивосток, Россия \\ *e-mail: nadyar@tigdvo.ru \\ **e-mail: lab39@mail.ru \\ Поступила в редакцию 16.12.2018 г. \\ После доработки 16.10.2019 г. \\ Принята к публикации 28.11.2019 г.
}

\begin{abstract}
Восстановлено развитие ландшафтов бассейна р. Раздольная в районе Старореченского городища. Получены фрагментарные данные для среднего голоцена ( 5.9 тыс. кал. л.н.), детально реконструкции проведены для последних 2.5 тыс. кал. л. Развитие ландшафтов проходило в контрастных климатических условиях, наиболее сильно изменялась увлажненность. Выявлено 5 этапов развития долины в условиях разной водности. Разрезы включают погребенную почву, сформированную в засушливый период во второй половине позднего голоцена, когда были широко распространены остепненные полынные, разнотравные луга и березовые редколесья. Климатические условия в конце VII-X вв. постепенно стали более теплыми и влажными. Снижение температуры при высоком увлажнении в малый ледниковый период с обновлением субстрата на пойме во время частых паводков привело к увеличению площадей, занятых сообществами березы овальнолистной. В лесной растительности низкогорья увеличилось участие сосны густоцветковой и берез. Проведена корреляция палеогеографических событий с региональными данными. Проанализирована роль антропогенного фактора в развитии ландшафтов во время заселения долины бохайскими земледельцами, первопоселенцами XIX - начала XX в. и при развитии современных агрокомплексов.
\end{abstract}

Ключевые слова: ландшафты, климатические изменения, паводки, средний-поздний голоцен, бохайское городище, первопереселенцы, Приморский край

DOI: $10.31857 / \mathrm{S} 2587556620020119$

\section{ВВЕДЕНИЕ}

Антропогенный фактор выходит на ведущие позиции в развитии геосистем не только в экономически развитых регионах РФ, но и на участках активного освоения в последние 150 лет, к которым относится юг Дальнего Востока. Для этой территории данные о природопользовании ограничены историческими сведениями, когда регион стал заселяться выходцами из западных областей России. Слабо изученным вопросом является оценка воздействия человека на природную среду в средневековье и более ранние эпохи. Не всегда есть информация о том, какой облик имели ландшафты до их преобразования в ходе хозяйственной деятельности. Целью работы является определение природных условий во время заселения бассейна р. Раздольной в средние века и выявление роли климатических изменений, на- воднений и антропогенных преобразований в развитии и трансформации долинных геосистем.

\section{РАЙОН ИССЛЕДОВАНИЙ}

Река Раздольная, трансграничная водная артерия, имеет истоки на территории КНР. В верховьях это горная река, в пределах России имеет равнинный характер. Работы проводились на участке расширения долины (до 20 км) в пределах Воздвиженской депрессии. Русло здесь активно меандрирует и характеризуется многорукавностью с обилием стариц. Выделяется 3 надпойменных террасы позднемиоцен-плиоценового и четвертичного возраста [23].

Климат муссонный, с большим температурным контрастом по сезонам по сравнению с побережьем [2]. Среднегодовая $t+3.2^{\circ} \mathrm{C}$, ср. $t$ января $-19.1{ }^{\circ} \mathrm{C}$, ср. $t$ августа $+20.9{ }^{\circ} \mathrm{C}$, абс. минимум 
$-38.8{ }^{\circ} \mathrm{C}$, максимум $+45.5{ }^{\circ} \mathrm{C}$, сумма активных температур 2600-2400 ${ }^{\circ} \mathrm{C}$. Долина открыта южным (48\%) и юго-восточным влажным ветрам. Среднегодовое количество осадков 622 м, максимум выпадает в августе (119 мм), максимальное суточное выпадение 198 мм зарегистрировано в 1950 г.

Режим р. Раздольная характеризуется низким весенним половодьем и 3-8 летне-осенними паводками. Питание реки преимущественно дождевое, сток талых вод $\leq 10 \%$. Примерно раз в 2 года частично затапливается пойма, раз в 7 лет проходят сильные паводки, раз в 16 лет - с подъемом уровня до 6 м, подъем уровня воды может достигать 5 м в сут. Вода отличается большой мутностью, в августе-сентябре проходит до 50\% годового объема твердого стока [10].

В верховьях хорошо выражена высотная поясность: лесостепная зона прослеживается до 200 м; кедрово-широколиственные леса - до 750 м; остепненные дубово-черноберезовые редколесья - до 550 м; елово-широколиственные леса - выше 700 м. Среднее течение относится к подзоне лесостепи [11]. Редколесья из дуба монгольского (Quercus mongolica) и березы даурской (Betula davurica), дубово-лещинно-леспедециевые заросли, злаковоразнотравные суходольные луга и степные участки сохранились фрагментарно. На низкой пойме развиты ольхово-ивовые и черемухово-ивовые, на высокой - широколиственные леса. Большая часть распахана и в настоящее время занята залежами.

Зона холмисто-увалистого рельефа (выс. до 200 м) отделяет Раздольненскую и Уссури-Ханкайскую впадины. С правого борта долина подходит к Борисовскому плато (выс. до 273 м) с широколиственными и хвойно-широколиственными лесами.

Долина начала осваиваться с конца XIX в. Село Старореченское возникло в 1903 г., численность населения (2010 г.) 247 чел. Специализируются на сельском хозяйстве, посевных площадей 56 тыс. га, из них $71 \%$ занято под зерновые культуры и сою.

\section{МАТЕРИАЛЫ И МЕТОДЫ}

Палеореконструкции проведены по разрезам отложений высокой поймы рядом со Старореченским городищем VII-X вв. н.э. [13] (рис. 1). Отбор проб проведен с шагом 3-5 см. Опробована почва с вершины вала. Диатомовый анализ выполнен по стандартной методике. Обработка проб для спорово-пыльцевого анализа проводилась по методу Эрдтмана. Для расчетов и построения диаграммы использовалась программа Tilia 2-0-41. В препаратах отмечалось присутствие углей. Радиоуглеродное датирование вы- полнено в Институте наук о Земле СПбГУ. Даты откалиброваны с помощью программы OxCal 4.2 (https://c14.arch.ox.ac.uk).

\section{РЕЗУЛЬТАТЫ}

Разрезы вскрывают две аллювиально-почвенных серии, формирование которых начиналось с пойменных отложений и заканчивалось образованием почв (см. рис. 1). Накопление отложений началось в среднем голоцене $\left({ }^{14} \mathrm{C}\right.$-дата $5150 \pm 140$ л.н., $5920 \pm 170$ кал. л.н., ЛУ-8855). Погребенная почва имеет позднеголоценовый возраст $\left({ }^{14} \mathrm{C}\right.$-даты $2110 \pm 80$ л.н., $2100 \pm 110$ кал. л.н., ЛУ-8854; $1610 \pm 110$ л.н., $1520 \pm 120$ кал. л.н., ЛУ-8856). Длительный перерыв в осадконакоплении связан с миграцией русла р. Раздольной. Возраст верхней части погребенной почвы VI-VII вв. н.э., когда возникло Старореченское городище. Образование второй аллювиально-почвенной серии началось в малый ледниковый период.

\section{Диатомовый анализ}

Сводный список диатомей включает 167 таксонов, преобладают эпифиты (78) и донные (76), планктонных и временно планктонных - 13 видов. По местообитанию виды разделены на две экологические группы: 1) Озерно-реофильные диатомеи, обитатели стоячих и текучих вод, показывают речное влияние. Встречаются обрастатели Epithemia adnata, E. turgida, E. sorex, E. hyndmannii, Cymbella turgidula, C. tumida, Rhopalodia gibba, Cocconeis placentula, C. placentula var. lineata, Staurosira venter, Ulnaria ulna и планктонный Aulacoseira italica. Из доминатов и субдоминантов современных сообществ [22] встречены Fragilaria vaucheriae, Reimeria sinuata, Cymbella turgidula, Melosira varians, Nitzschia linearis, Navicula cryptocephala, Cymbella affinis. 2) Почвенные виды, способные обитать при незначительном увлажнении и переносить временное высыхание субстрата: Luticola mutica, Humidophila contenta, Pinnularia borealis. Наиболее обилен Hantzschia amphioxys (до 82\%), характерный для пойм. Выделено 8 комплексов, отражающих разные гидрологические обстановки (рис. 2).

- Из диатомей первой группы часто встречаются обрастатели Epithemia adnata, E. turgida, E. hyndmannii. Низкое содержание створок связано с сильным терригенным разбавлением.

- Содержание почвенных диатомей достигает $38.9 \%$. В составе аллохтонных диатомей преобладают обрастатели (до 58\%), планктонных $\leq 7 \%$. Высокого обилия достигают виды, характерные для олиготрофно-мезотрофных вод. Пик содержания Aulacoseira italica фиксирует прохождение сильного паводка. Отмечены Staurosira venter, S. subsalina, Staurosirella pinnata, Eunotia formica, 

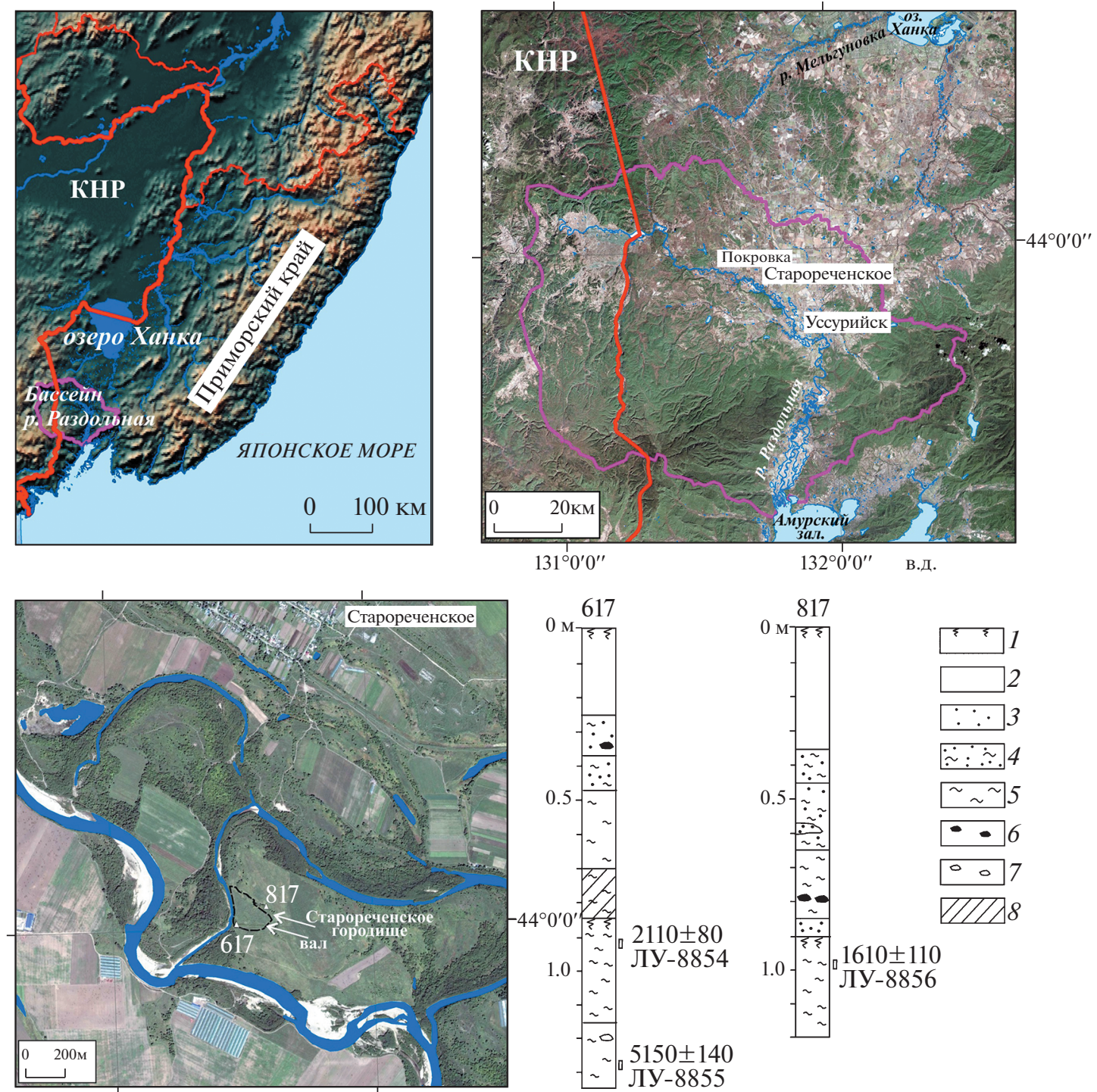

$131^{\circ} 43^{\prime} 0^{\prime \prime}$

$131^{\circ} 44^{\prime} 0^{\prime \prime} \quad$ в.Д.

Рис. 1. Схема района работ, положение и строение изученных разрезов 617 (археологический шурф 1) и 817 (археологический шурф 6).

1 - почва, 2 - антропогенно измененный горизонт, 3 -песок, 4 - супесь, 5 -суглинок, 6 - уголь, 7 - галька, 8 - культурный слой.

населяющие, преимущественно, стоячие воды. Возможно, рядом существовала старица.

- Обилие почвенных видов (до 49\%) отражает дальнейшее развитие почвенных процессов. Повышается доля Staurosira venter, S. construens, Staurosirella pinnata, а также Cymbella turgidula. Появляются характерные для текучих вод Meridion circulare, Gomphonema trunctatum Fragilaria vaucheriae. Увеличение доли аллохтонных видов свидетельствует о начале периода частых паводков.

- Доля почвенных диатомей снижается ( $\leq 16 \%)$. Среди обрастателей появляется Cymbella tumidula и реофил Reimeria sinuata. Обилие диато- мей, поступавших с речными водами, указывает на регулярное прохождение паводков.

- Встречены преимущественно виды, характерные для речных вод. Снижение видового богатства (от 61 до 5 таксонов) и содержания створок связано с терригенным разбавлением.

- Содержание почвенных диатомей повышается до 39\%, заметную роль играли Pinnularia borealis и Luticola mutica. Это свидетельствует о снижении частоты паводков и активизации почвенных процессов.

- Доля почвенных диатомей $\leq 17.8 \%$. Значительно повышается содержание Cymbella turgidu$l a$, появляются населяющие стоячие воды Neidio- 

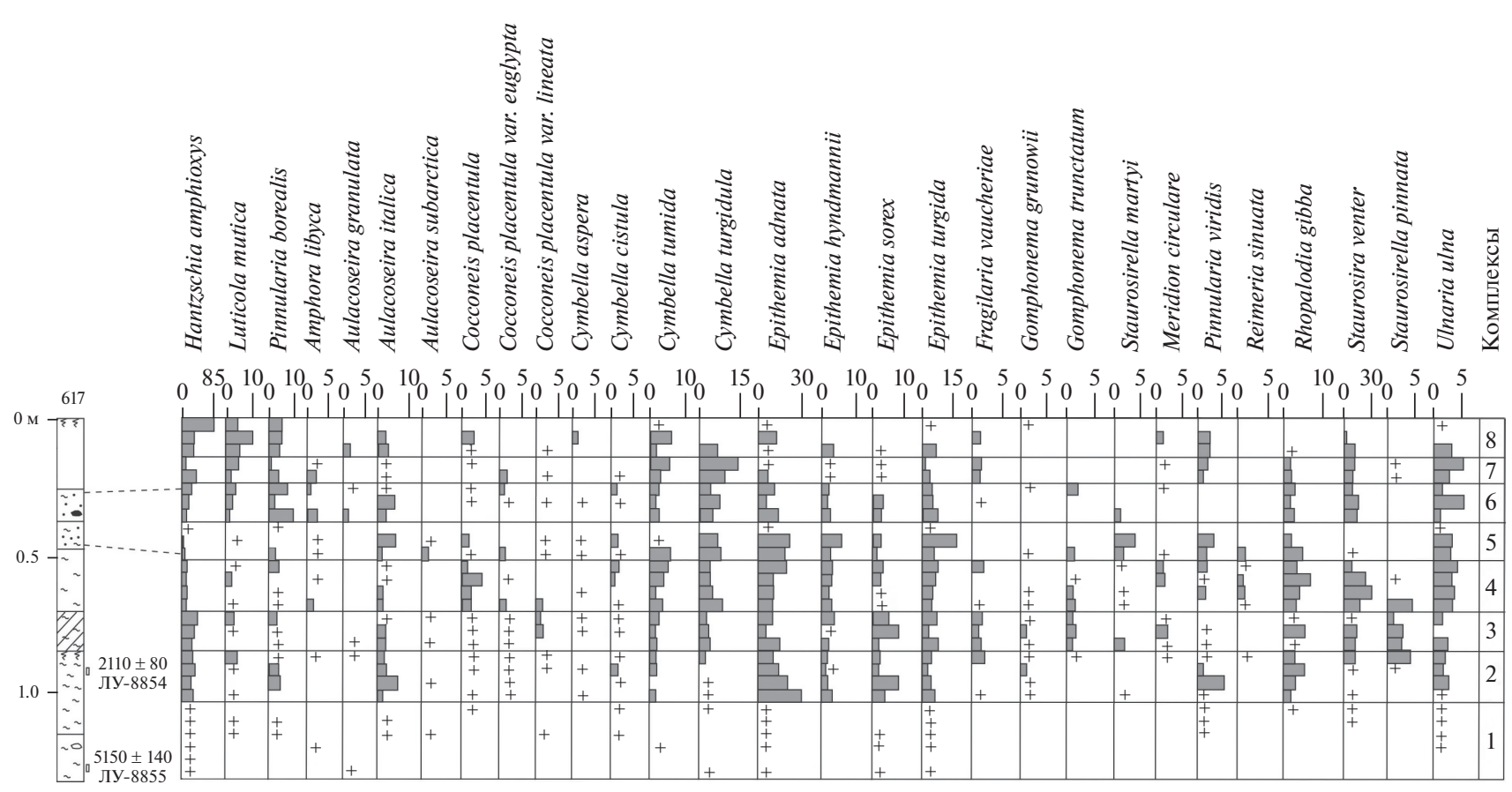

Рис. 2. Распределение диатомей в отложениях разреза 617, пойма р. Раздольная.

morpha binodis (12\%), Halamphora montana, Frustulia vulgaris и обитающая в заболоченных местах $E u$ notia praerupta. Комплекс указывает на прохождение сильных паводков.

- Наблюдается рост содержания почвенных видов (до 92\%), что указывает на развитие почвенных процессов и снижение частоты паводков. Характерно снижение видового богатства (от 30 до 12) и частые смены доминант.

В почве на вершине вала доминируют Hantzschia amphioxys (75.5\%) и Pinnularia borealis (22.6\%). Среди видов, принесенных наводнениями, отмечены Cymbella aspera и C. turgidula. Состав диатомей свидетельствует о сухих условиях, но во время сильных паводков вал затапливался.

\section{Спорово-пыльцевой анализ}

Палиноспектры включают большое количество аллохтонной пыльцы, которая занесена, главным образом, водным путем с верхних частей бассейна. Выделены 6 палинозон и фаз развития растительности (рис. 3):

1) В условиях высокой водности ольха имела ограниченное распространение на пойме. Встречено много пыльцы жимолостных, есть пыльца смородины, поступавшая со склонов, и кустарниковой березы из долинных сообществ. На сырых участках росли лютиковые, гречишные, капустовые, вересковые. Найдена пыльца филлантуса уссурийского, обитателя галечных берегов и сырых лугов. В старицах встречалась уруть. Высо- кие уровни занимали остепненные луга с полынными и разнотравными сообществами. Бобовые были распространены в сообществах на различных местообитаниях - от сухих с участием леспедецы двухцветной (Lespedeza bicolor) до влажных. В широколиственных лесах росла маакия амурская (Maackia amurensis). Пыльца розоцветных объединяет представителей луговой и древесной растительности - на сухих каменистых склонах мог расти абрикос маньчжурский (Armeniaca mandshurica); по сырым лугам - Spiraea salicifolia. Присутствуют споры папоротников, плаунов и ксерофита плаунка сибирского (Selaginella sibirica), который мог расти на скалах. Находки углей свидетельствуют о частых пожарах, что закономерно при контрастах в увлажненности по сезонам.

2) В долине небольшие участки занимали березовые редколесья, на пойме - ольшаники. Развитие кустарниковой березы с вересковыми кустарниками отвечает более холодному климату, чем современный. В низкогорье были фрагменты широколиственных лесов с участием граба, лещины, диморфанта, на осветленных участках аралии, росла смородина. Распространение получил абрикос маньчжурский - обилие пыльцы розоцветных не характерно для луговых спектров [24]. На пойме на увлажненных участках росли лютиковые, зонтичные, ирисовые, гречишные, вьюнковые, свидина белая (Swida alba), в старицах - уруть. Высокие поверхности занимали ксерофитные группировки полыни и разнотравные луга. Встречена пыльца зимолюбки японской 


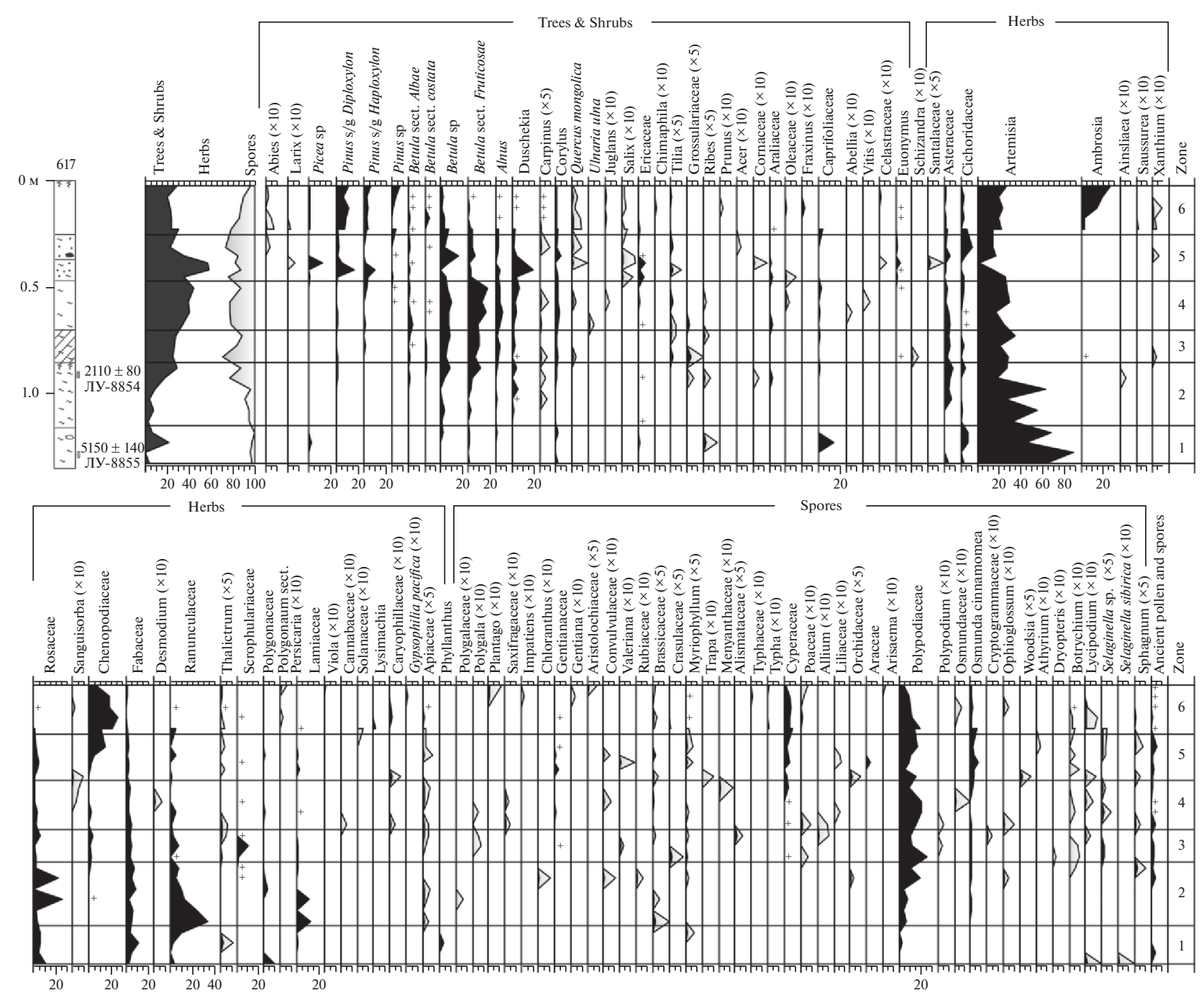

Рис. 3. Спорово-пыльцевая диаграмма отложений разреза 617, пойма р. Раздольная.

(Chimaphila japonica), которая росла в хвойно-широколиственных лесах; хлоранта японского (Chloranthus japonicus), копытня (Asarum), встречающихся в лиственных и смешанных лесах. Рост доли спор в верхней части отвечает более частым паводкам.

3) Залесенность территории увеличилась: на высоких уровнях стали распространены березовые леса, в долине - ольшаники, на переувлажненных местообитаниях - кустарниковая береза. На влажных участках поймы встречались лютиковые, осоковые, зонтичные, капустовые, валериана, частуховые. Остепненные луга были также представлены. Из ксерофитов найдена пыльца истода тонколистного, современный ареал которого ограничен Приханкайской низменностью и районом около г. Лесозаводска. На скалах, осыпях, галечниках и в сырых лесах встречались толстянковые, на скалах - плаунки и криптограммовые папоротники. Найдена пыльца луковых, дур- нишника, амброзии. С горных склонов поступала пыльца Pinus s/g Diploxylon, вероятно, сосны густоцветковой (Pinus densiflora) и березы ребристой (Betula costata). В низкогорье стали более распространены кедрово-широколиственные леса с лещиной, бересклетами, жимолостями, лимонником и папоротниковым покровом. Более активно шел перенос пыльцы водным путем с верховий долины.

4) На пойме стали более развиты сообщества кустарниковой березы с вересковыми кустарниками и сфагновыми мхами и ольшаники; на высоких уровнях - березовые леса с березой ребристой. Ветровой и водный занос пыльцы шел из кедрово-широколиственных лесов: встречена пыльца кедра корейского (Pinus koraiensis), дуба, ореха, ильма, липы, граба, диморфанта, лещины и бересклета. На осветленных участках было много аралии, винограда. Найдена пыльца Abelia, предпочитающего скалистые местообитания, и под- 
окарпиума маньчжурского (Podocarpium mandshuricum), произрастающего под пологом умеренно увлажненных лиственных лесов. В наземном покрове преобладали папоротники при участии чистоустника азиатского, ужовника, гроздовника. В долине стали более широко развиты остепненные луга с полынными и разнотравными сообществами. На увлажненных участках поймы росли лютиковые, осоковые, кровохлебка, зонтичные, гречишные, капустовые, лилейные, луковые. На скалах и курумниках в горах в изобилии были плаунок, камнеломковые. Представители семейства Saxifragaceae могли встречаться в долинных лесах (Chrysosplenium) и на сырых лугах (Astilbe). Найдена пыльца коноплевых, возможно, заносной конопли посевной (Cannabis sativa), но нельзя исключать, что это пыльца японского хмеля (Humulopsis scandens).

5) В условиях улучшения дренажа и роста температур сократилась площадь, занятая сообществами кустарниковой березы. Березовые леса получили большее развитие. Пыльца пихты и ели поступала, главным образом, с верховьев. Пыльца лиственницы также могла быть перенесена с плато и верховий реки. На пойме были заросли ольхи, ивняки, большее распространение получили ольховник, вересковые кустарники и кустарнички. В бассейне реки большие площади стала занимать сосна густоцветковая. В низкогорье были распространены кедрово-широколиственные леса с папоротниковым покровом. Во влажных лесах встречались ароидные. Среди пыльцы трав стало меньше таксонов, предпочитающих сухие местообитания. Разнотравные луга остаются главным элементом долины. Найдена пыльца качима тихоокеанского (Gypsophila pacifi$c a)$, характерного для остепненных лугов с арундинеллой [16]. На скалах росли вудсия, плаунки. Из трав, предпочитающих увлажненные участки, встречена пыльца осок, лютиковых, капустовых, зонтичных, кровохлебки, валерианы. В старицах появился водяной орех, на переувлажненных участках - вахтовые. Из заносных растений найдена пыльца дурнишника. Отмечен рост содержания пыльцы маревых и цикориевых.

6) Палиноспектры отвечают развитию луговой растительности и пашен. Пыльца древесных отражает распространение хвойно-широколиственных лесов на плато и в низкогорье. Резко увеличилась доля пыльцы сосен. Снижение доли пыльцы древовидных берез отражает тенденцию вовлечения земель в сельскохозяйственное использование. Из долинных сообществ исчезла кустарниковая береза. На пойме сохранились ивняки, почти исчезли ольшаники - возможно, стало суше. Среди трав на ведущую позицию выходят маревые, вероятно, за счет распространения рудеральных видов на полях. Появляется пыльца амброзии полыннолистной (Ambrosia artemisiifo- lia), одного из агрессивных заносных растений [18]. Наряду с дурнишником, встречена пыльца растений, которые сопутствуют крупным поселениям (подорожник), по берегам рек и канав стали часто встречаться горцы. Отмечен рост доли пыльцы Роасеае в поверхностной почве. В долине и на увалах широко распространены луга, на сухих местообитаниях - полынные и разнотравные сообщества. Площади, занятые сырыми лугами постепенно сокращались. На начальном этапе формирования почвы более широко были представлены плауны, что характерно для пионерных группировок.

В разрезе встречены переотложенные споры Cyatheaceae, Schizaea из угленосных нижнемеловых отложений [5]; пыльца Sterculiaceae, Firmiana, Engelhardtia, Casuarina, споры Lygodium, характерные для палеогена [23], и споры Dicranopteris, представителя неогеновых флор [1].

В палиноспектре из почвы вала преобладает пыльца сосен (Pinus s/g Diploxylon 19.3\%, Pinus s/g Haploxylon 3.5\%), найдены Abies, Picea, Betula, Quercus, Ulmus, Carpinus, Tilia ветрового заноса. Присутствует пыльца Alnus, Salix. Среди пыльцы трав встречены Artemisia (19.3\%), Ranunculaceae (14.3\%), Polygonaceae (13\%), Fabaceae (8.4\%), Ambrosia (4\%) Poaceae, Cyperaceae, Rosaceae, Apiaceae, Chenopodiaceae, Lamiaceae, Asteraceae, Cichoridaceae, Xanthium. Источником пыльцы Tanacetum могут быть разнотравно-пижмовые луга речных террас, которые относятся к редким сообществам [16]. Обнаружена Ephedra. Спор мало, доминируют Polypodiaceae и Osmunda cinnamoтеа, единичны Sphagnum и Sterculiaceae. Из непыльцевых палиноморф интересны находки спор грибов, которые поражают культурные растения. Найдены споры сапротрофного Byssothecium circinans, паразита различных растений, в том числе, люцерны. Обнаружен Риссіпіа, возбудитель ржавчины, поражающей пшеницу, ячмень и другие злаковые. Встречен Glomus, препараты с этими спорами используют как биологический стимулятор роста растений для повышения урожайности и усиления иммунитета. Найдена коловратка Rotatoria, которая могла быть занесена в паводки.

\section{ОБСУЖДЕНИЕ РЕЗУЛЬТАТОВ}

Палеогеографический материал, полученный по аллювиальным отложениям в долинах горных рек, имеет свою специфику. Палиноспектры из отложений, сформированных в паводки, отражают интегральную характеристику долины [13], набор диатомей также является смесью автохтонных и аллохтонных видов. Действие природных факторов осложняется влиянием человека в средние века и, особенно, при освоении долины с XIX в. 


\section{Климатический контроль над развитием ландшафтов}

Разрезы высокой поймы р. Раздольная запечатлели два этапа в развитии ландшафтов: фрагментарно конец среднего голоцена ( 5.92 тыс. кал. л.н.) и более детально последние 2.5 тыс. л.

Средний голоцен в Приморье характеризовался теплыми (среднегодовые $t$ выше современных на $\sim 3{ }^{\circ} \mathrm{C}$ ) и влажными условиями, количество среднегодовых осадков на побережье составляло 900-1200 мм, а на равнинах Западного Приморья 600-700 мм [14]. В конце периода в речных долинах началась активная аккумуляция материала. Высокая водность фиксируется и в долинах водосбора оз. Ханка [3]. В бассейне р. Раздольная на высоких поверхностях были распространены остепненные луга с участием полыни, разнотравья и обилием леспедецы. В горном обрамлении Приханкайской равнины и верховьях долин в Восточно-Маньчжурских горах были развиты широколиственные и кедрово-широколиственные леса с более широким участием термофилов, чем в настоящее время $[3,4]$. В луговой растительности широкое распространение получили гидрофитные сообщества [3].

Погребенная почва начала формироваться при снижении увлажнения в похолодание $\left({ }^{14} \mathrm{C}\right.$-даты $2110 \pm 80$ л.н., $2100 \pm 110$ кал. л.н.; ЛУ-8854; $1610 \pm 110$ л.н., $1520 \pm 120$ кал. л.н., ЛУ-8856). Увеличение численности Hantzschia amphioxys и Pinnularia borealis отмечено и в отложениях в нижнем течении р. Раздольная, образованных $\sim 1.88$ тыс. кал. л.н. [28]. Тенденция к иссушению 3.12.7 тыс. кал. л.н. отмечена для болотных массивов Сихотэ-Алиня, особенно засушливые условия были 2.7-2.0 тыс. кал. л.н. [25, 26]. В юго-западном Приморье при более высоких температурах и меньшем влиянии влажных воздушных масс, условия могли быть еще более засушливыми. Снижение увлажнения зафиксировано и в разрезах пойменных отложений Приханкайской равнины [3]. Уровень озера был низким 21 тыс. кал. л.н. [15]. Из торфа выше озерных глин получена ${ }^{14} \mathrm{C}$-дата $1525 \pm 45$ л.н., $1420 \pm 60$ кал. л.н., COAH-5527 [21].

В долине р. Раздольной более широкое развитие получили остепненные полынные, разнотравные луга, заросли леспедецы и березовые редколесья. На пойме небольшие площади занимали ольшаники, увлажненные местообитания сокращались. На плохо дренированных участках разрасталась береза овальнолистная, чему способствовали частые палы [12].

Выделенный этап развития ландшафтов хорошо сопоставляется с региональными данными. На Приханкайской равнине были распространены остепненые луга, береза становится доминантом среди древесных видов. В долинах рек 2.69-
2.48 тыс. кал. л.н. были широко представлены злаковые, разнотравные степи, в предгорьях - березовые леса с участием кедра корейского и широколиственных [4].

Средневековое потепление в бассейне р. Раздольная проявилось слабо. Биоиндикаторы отражают увеличение увлажненности климата. В долине большее распространение получили ольшаники, группировки с березой овальнолистной и травяные сообщества, предпочитающие увлажненные местообитания, на высоких уровнях - березовые леса. Кустарниковая береза стала более распространена с похолодания VI в. н.э., проявленного и на Приханкайской равнине [3]. Попрежнему в ландшафтах бассейна р. Раздольная были широко представлены остепненные луга. Состав аллохтонной пыльцы свидетельствует о развитии кедрово-широколиственных лесов в низкогорье. В предгорьях Приханкайской равнины расширились площади лесных ландшафтов, возросла роль термофилов; более облесенными стали долины рек [3]. Уровень озера поднялся в VII-XII вв. [22].

При высоком увлажнении в малый ледниковый период на пойме увеличились площади, занятые березой овальнолистной с вересковыми кустарниками, осоками и сфагновыми мхами. Аналогами таких ландшафтов могут быть минерогенные болота на севере Приморского края. На высоких поверхностях в бассейне р. Раздольная более широкое развитие получают остепненные полынные и разнотравные луга. В кедрово-широколиственных лесах низкогорья увеличилась роль берез. В завершаюшую фазу малого ледникового периода в условиях повышения водности на пойме стали распространены ивняки. Сообщества кустарниковой березы сократили участие. Среди аллохтонной пыльцы появились темнохвойные виды. В лесной растительности низкогорья и водораздела, отделяющего бассейн р. Раздольной от Приханкайской низменности, увеличилась роль сосны густоцветковой и берез. В лесах Приханкайской равнины отмечено снижение разнообразия широколиственных, в долинах рек появилась кустарниковая береза [3]. В обрамлении оз. Ханка большее распространение получают лесостепные ландшафты [21], в лесах снизилось разнообразие широколиственных, в долинах рек появилась кустарниковая береза [3]. Регрессии озера происходили в холодные и сухие фазы XII-XIV и XIV-XIX вв. [21].

\section{Динамика паводков}

Осадконакопление в долине происходило в условиях неравномерной повторяемости паводков, интенсивность и частота которых контролировались климатическими изменениями, связанными с перестройками атмосферной циркуляции. 
Надежными свидетельствами паводков помимо литолого-фациальных признаков являются биоиндикаторы, прежде всего, изменение соотношения аллохтонных и автохтонных диатомей, а в палиноспектрах - доли пыльцы и спор, перенесенных водным путем с верховьев водосбора.

Изученные разрезы фиксируют 5 этапов развития долины в условиях разной водности р. Раздольной: 1) завершающий этап среднего голоцена с активной аккумуляцией наносов в условиях полноводной реки; 2) длительный этап снижения водности, начавшийся в похолодание 2.7 тыс. л.н. и длившийся около 1400 лет, когда на пойме образовалась мощная почва; 3) умеренно влажная фаза средневековья, когда существовало городище; 4) влажные фазы малого ледникового периода с накоплением пойменных суглинков и супесей; 5) небольшое снижение водности, когда начала формироваться поверхностная почва (предположительно с XIX в.).

Развитие погребенной почвы в засушливых условиях происходило при снижении интенсивности летнего муссона. В этот период периодически проходили сильные паводки, но повторяемость их была явно реже, чем в современных условиях. Об их прохождении свидетельствует на фоне преобладания диатомей типичных для пойменных почв, постоянное присутствие видов из других биотопов (старицы, болотистые участки и др.), которые могли быть занесены только речными водами. Судя по пику содержания планктонных видов рода Aulacoseira, наиболее сильные наводнения на фоне иссушения поверхности поймы проходили в теплую фазу (выше из почвы получена ${ }^{14} \mathrm{C}$-дата $2110 \pm 80$ л.н., $2100 \pm 110$ кал. л.н., ЛУ-8854). Признаками сильных паводков могут быть переотложенные пыльца и споры из древних отложений и увеличение количества пыльцы и спор, которые переносились водным путем. Низкая водность рек отмечена и для водосбора оз. Ханка [3]. Регрессия озера датируется 1400-1500 л.н. [21]. Снижение обводнения долины и частоты паводков 2240-1260 кал. л.н. характерно и для бассейна р. Бикин [26].

В средние века в долине р. Раздольной ситуация мало поменялась. Когда образовалось городище ( конец VII в. н.э.) еще длился сухой период. Озеро Ханка в VI-VII вв. находилось в регрессивном положении [21]. В малый оптимум голоцена в бассейне Раздольной паводки стали более частыми, о чем свидетельствует рост содержания аллохтонных диатомей. Но кардинальных изменений ситуации не было: в культурном слое доминируют виды, типичные для почв. Озеро Ханка в VIII-XII вв. имело высокий уровень, следы паводков четко запечатлены в разрезах пойменных отложений [3]. На Бикине период с обильным речным стоком и частыми паводками выделяется 1260-720 кал. л.н. [26].

Водность р. Раздольная резко увеличилась в малый ледниковый период: возросла частота паводков, затапливалась вся пойма, и шло накопление суглинков без следов длительных перерывов. Накопление суглинков отмечено на поймах рек бассейна оз. Ханка [3]. Подъем уровня озера был $\sim 720$ и 570 кал. л.н. [16]. Сухая фаза выделяется $\sim 480$ кал. л.н. [22]. Возможно, как и в бассейне Бикина [26], ход паводков в долине р. Раздольной был неравномерным и совпадал с теплыми фазами малого ледникового периода. Высокая доля видов, характерных для стариц, косвенно указывает на их широкое развитие при меандрировании и смене положения русла. Накопление супесей, по-видимому, происходило в период усиления паводковой активности, речные взвеси стали более грубыми, шла более активная эрозия. В составе диатомей из более грубых слоев пойменных отложений р. Раздольная преобладают виды, характерные для речных вод. Сильно увеличилось количество пыльцы и спор водного переноса с верховий из пояса темнохвойных лесов. В большем количестве приносилась пыльца из кедрово-широколиственных лесов низкогорья и из сосновых лесов. Стало больше переотложенной пыльцы и спор. По аналогии с бассейном p. Бикин можно предположить, что регулярные паводки стали происходить последние 220 лет [26]. Подъем уровня оз. Ханка был в середине XVIII-XIX столетиях [15].

Рост вверх по разрезу содержания створок диатомей, характерных для почв, указывает на снижение паводковой активности и развитие почвенных процессов. На момент заселения долины первопоселенцами на пойме р. Раздольная сформировалась плодородная почва, которую начали использовать под пашни. Понижение уровня оз. Ханка на $\sim 0.6-0.9$ м, вероятно, за счет снижения увлажнения, было отмечено в 1866-1893 гг. [7].

Наводнения стали главным бедствием переселенцев, тем более что они совпадали с периодами уборки урожая и заготовки сена. Сильные паводки на р. Раздольная отмечены в 1880, 1901, 1905 и 1910 гг. [17]. Описание наводнений оставил Н.А. Крюков [19], обследовавший условия землепользования в конце XIX в.: "и тогда горе земледельцам: бурная стихия не только может унести сжатый хлеб и накошенное сено, затопить гуляющий скот, но она коверкает и портит до неузнаваемости саму почву: где был чернозем, оказываются чистые пески, где был бугор, оказывается яма, где было углубление, может остаться сплошная масса илу и т.п.”. Он предлагал “единственное радикальное средство борьбы с внезапными и всеразрушающими наводнениями есть урегулирование рек путем сдвига их двумя земляными плоти- 
нами". И далее пишет: “В разных местностях Уссурийского края мне приходилось натыкаться иногда на окопанные высокими валами пространства; многие думают, что это бывшие крепости, которые были будто бы выстроены против нападений разбойников. Мне же эти так называемые крепости представляются плотинами, которыми немногочисленное земледельческое население, обитавшее здесь в прежнее время, ограждало свои поля, чтобы навсегда избавиться от наводнений”.

Паводки остались грозным явлением. Экстремальный поводок на р. Раздольной был в 2012 г., когда сформировались редкие термобарические условия с выходом тропического циклона в сентябре на территорию Южного Приморья на фоне переувлажнения водосборов и высокого уровня воды в реках [8]. Оценка вероятности такого события 1 раз в 500-1000 лет, по-видимому, слишком оптимистическая. В последние сильные паводки 07.08.2017 и 28.08.2018 были затоплены большие площади высокой поймы, вода подошла к с. Старореченское, у фермеров унесло сено и смыло урожай.

\section{Роль антропогенного фактора}

Палиноспектры из культурного слоя городища в основном отражают природные изменения ландшафтов. Пыльца культурных злаков не найдена. Если и были посадки сои, увеличения содержания пыльцы бобовых не зафиксировано. Нет и пыльцы гречишных. Найдена пыльца луковых, но она могла принадлежать и черемше, распространенной около рек. Пыльца коноплевых встречена чуть выше культурного слоя, нельзя исключать, что коноплю посевную выращивали в средневековье. Можно предположить, что недалеко росла смородина, и ветки могли использовать в бытовых целях. Интерес представляет находка пыльцы амброзии, что подтверждает данные о возможности произрастания этого заносного растения в бохайских поселениях. Пыльца амброзии найдена в пойменных отложениях малого оптимума голоцена р. Комиссаровки [18].

В культурном слое найдена пыльца дурнишника - сорного однолетнего растения, появившегося в Китае с 2100 кал. л.н. [29]. Находки пыльцы Xanthium strumarium рассматриваются, как свидетельство сельскохозяйственной деятельности 2000-1800 кал. л.н. [30]. Эта пыльца встречается в одновозрастных отложениях оз. Сихайлонгван [31]. Пыльца полыни также могла поступать с городища - отмечен рост ее содержания (40\%) по сравнению с подстилающей почвой (22-31\%).

Остается открытым вопрос о пыльце и спорах из меловых и палеогеновых угленосных отложений. Может ли их наличие быть признаком использования угля в древнем поселении? В бассей- не р. Раздольной есть и крупные месторождения, которые разрабатывают открытым способом. До революции уголь добывали на территории Никольск-Уссурийска, использовали выходы на сопке у пос. Красный Яр [19]. Нельзя исключать антропогенный источник наряду с процессом переотложения за счет боковой эрозии при сильных паводках.

Коренная трансформация ландшафтов долины произошла при освоении края с конца XIX в. Поскольку почва в долине регулярно перепахивалась, палиноспектры являются осредненными за достаточно большой промежуток времени, поэтому присутствует как пыльца растений, широко представленных в природных сообществах, так и пыльца апофитов. Ближайшее к городищу крупное с. Покровское появилось в 1881 г. на месте станицы Старофадеевки, до этого здесь были китайские пашни [7]. Лесных угодий в наделе у села не было [19], использовали любой строевой лес, китайцы сплавляли его с верховьев реки из Маньчжурии [7]. Высокое содержание пыльцы сосны густоцветковой в поверхностной почве свидетельствует о ее широком развитии в предгорьях до заселения и активного уничтожения лесов. Бассейн р. Раздольной входит в ареал этого вида [16], но больших насаждений нет. До освоения края они были на хребтах, разделяющих реки Раздольную и Илистую, и по берегам оз. Ханка [6]. Ветровой занос пыльцы сосен на достаточно большое расстояние известный факт [13, 24]. Возможно, источником пыльцы сосен могут быть посадки в близлежащих поселках, но вряд ли их влиянием можно объяснить высокое содержание пыльцы Pinus s/g Diploxylon в спектрах.

Первой культурой, которой засевали новь, была гречиха, с ее помощью разрыхляли землю, избавлялись от сорняков и готовили под посевы пшеницы и ржи [7]. Сеяли в июне-начале июля, поэтому цветение совпадало с дождливым временем, тем не менее, пыльцы гречихи в палиноспектрах нет. Основными культурами были пшеница, рожь, в меньшей степени - овес. Ячмень и просо сеяли в ограниченных количествах. Кукурузу почти не сеяли. Для себя производили лен и коноплю. Из овощей выращивали, главным образом, картофель, капусту, лук. В с. Покровка использовали переложную систему полеводства, отправляя поле каждые два года под залежь [19]. Несмотря на то, что основными культурами, которые сеяли в XIX-начале XX в., были хлеба, палиноспектры из поверхностной почвы содержат мало злаковых. Пыльца культурных злаков не найдена. Несоответствие роли злаковых в спектрах реальному их участию в растительности отмечалось раHee [24].

Землю сдавали корейским арендаторам, которые предпочитали плодородные поля у реки. На- 
бор культур тут был другой, сеяли просо, бобы, овес, кукурузу, ячмень и очень редко пшеницу, использовали всегда однопольную систему [19]. Ближайшим корейским селением было Синельниково.

Сою наряду с рисом начали более активно сажать на полях Приморья в 1920-х годах [27]. Сейчас это одна из основных посевных культур района. Но в палиноспектрах пыльцы бобовых стало меньше по сравнению с более древними осадками. Пыльца капустовых стала встречаться чаще, возможно, за счет распространения сорных видов из этого семейства. В супеси под пашенным слоем найдена пыльца пасленовых, но нет уверенности, что это пыльца картофеля - могут быть и дикорастущие виды паслена. В бассейне р. Раздольной известны два вида: Solanum kitagawae - паслен Китагавы и Physiliastrum echinatum - физилиаструм иглистый. Среди плодовых деревьев и кустарников первопоселенцы предпочитали сливу, местную яблоню, крыжовник, смородину красную и черную, малину [7, 19]. За исключением сортов, предпочтения мало изменились. В палиноспектрах встречена только пыльца сливы, популярной садовой культуры. Пыльцы розоцветных стало меньше, чем в подстилающих супесях.

Из растений, сопутствующих человеческому жилью, отмечается пыльца подорожника и горцев. Часть видов может расти около человека, другие природные. Регулярно встречается пыльца цикориевых. Заметное увеличение пыльцы маревых, вероятно, отражает распространение рудеральных видов этого семейства на полях.

Из Европейской части России первопоселенцами был завезен дурнишник, пыльца которого встречена в разрезе. Его современное распространение является второй волной инвазии. В спектре из поверхностной почвы наблюдается высокое содержание пыльцы амброзии полыннолистной. Этот вид является палеоинвазивным, появился в Приморье в позднем неолите, исчез к середине XIX в. [18]. В окрестностях с. Старореченское амброзия, скорее всего, стала распространяться в 1960-х годах. Но нельзя забывать, что первопереселенцы еще в XIX в. пробовали сажать калифорнийскую пшеницу, выписывали из Америки семенной материал картофеля; фермер Гек заказал в Калифорнии семена сахарного сорго [7]. В почве на валу встречены споры грибов, которые поражают злаки, бобовые, что также можно рассматривать, как биоиндикацию широкого развития агроландшафтов.

В поверхностном слое почвы из состава аллохтонных диатомей исчезли многие виды-олигосапробионты, их содержание $\leq 5 \%$. Заметным становится участие $\beta$ - и $\alpha$-мезосапробионтов $-E p i$ themia adnata, E. turgida, Ulnaria ulna, Pinnularia viridis, Sellaphora pupula, Navicula rhynchocephala, имеющих индекс сапробности $\geq 1.6$, что показывает повышение содержания органических веществ в воде. Оценка качества воды в р. Раздольной выше г. Уссурийска оценивается как умеренно загрязненное [22]. Следует отметить, что вид Aulacoseira italica входил в состав доминант речных вод в позднем голоцене, в современных сообществах видов рода Aulacoseira нет среди доминант и субдоминант [22]. Возможной причиной может служить усиление органического загрязнения, как российской, так и китайской территории [20].

\section{ВЫВОДЫ}

Анализ фациальных взаимоотношений в разрезах и данные биостратиграфических анализов позволили восстановить развитие ландшафтов среднего течения р. Раздольная и близлежащих водоразделов, которое контролировалось климатическими изменениями, в первую очередь, контрастными условиями увлажнения. Остепненные луга с участием полыни и разнотравья были распространены во второй половине среднего голоцена, горное обрамление занимали широколиственные и кедрово-широколиственные леса с широким участием термофилов. Длительный засушливый период (2.7-1.3 тыс. кал. л.н.) привел к образованию погребенной почвы. Увлажненные местообитания постепенно сокращали свои площади на пойме. На плохо дренированных участках появилась кустарниковая береза. В средневековое потепление при прогрессирующем увеличении увлажнения большее распространение получили ольшаники, группировки с березой овальнолистной и травяные сообщества, предпочитающие увлажненные местообитания, на высоких уровнях - березовые леса. В малый ледниковый период при достаточно высоком увлажнении на пойме увеличились площади, занятые сообществами березы овальнолистной, на речных террасах и увалах - остепненными лугами. В составе кедровошироколиственных лесов низкогорья увеличилось участие берез, на близлежащих водоразделах - cocны густоцветковой. Усилился водный перенос пыльцы и спор из лесов верховий долины. Палиноспектры из поверхностной почвы отражают широкое распространение сосны густоцветковой до заселения района и активного уничтожения лесов.

Развитие долинных ландшафтов происходило в условиях неравномерной повторяемости наводнений. Установлено 5 этапов развития долины: 1) многоводный этап второй половины среднего голоцена; 2) снижение водности в позднем голоцене с наводнениями редкой повторяемости; 3) умеренно влажная фаза средневековья; 4) влажные фазы малого ледникового периода; 5) снижение водности во второй половине XIX в. 
Воздействие человека на ландшафты в средневековье было минимальным. Найдены лишь признаки присутствия некоторых сорных растений, включая амброзию. Коренная трансформация ландшафтов началась при заселении переселенцев в конце XIX в. и последующем освоении территории. Пыльца культурных растений в почве встречена в небольших количествах, наблюдается высокое содержание пыльцы амброзии полыннолистной, рудеральных растений и апофитов, найдены споры грибов, поражающих сельскохозяйственные культуры. Сравнение состава аллохтонных диатомовых водорослей, поступавших на пойму во время сильных паводков в позднем голоцене, с современными сообществами, указывает на усиление поступления органических веществ при активном освоении долины.

\section{ФИНАНСИРОВАНИЕ}

Работа выполнена при финансовой поддержке “Приоритетных научных исследований в интересах комплексного развития ДВО РАН”, (проект ВАНТ 18-010).

\section{FUNDING}

The work was carried out with the financial support of the program "Priority Research for the Integrated Development of the Far Eastern Branch of the Russian Academy of Sciences" (project VANT 18-010).

\section{СПИСОК ЛИТЕРАТУРЫ}

1. Аблаев А.Г., Васильев И.В. Миоценовая краскинская флора Приморья. Владивосток: Дальнаука, 1998. $107 \mathrm{c}$.

2. Агроклиматические ресурсы Приморского края. Л.: Гидрометеоиздат, $1973.148 \mathrm{c.}$

3. Базарова В.Б., Лящевская М.С., Макарова Т.Р., Орлова Л.А. Обстановки осадконакопления на поймах рек Приханкайской равнины в среднем-позднем голоцене (юг Дальнего Востока) // Тихоокеан. геол. 2018. Т. 37. № 1. С. 94-105.

4. Болиховская Н.С., Воскресенская Т.Н., Муратова М.В. $\mathrm{K}$ стратиграфии и палеогеографии позднеплейстоценовых и голоценовых отложений Приморья // Геохронология четвертичного периода. М.: Наука, 1980. C. 254-258.

5. Бугдаева Е.В., Маркевич В.С. Исходный растительный материал уникальных меловых углей Липовецкого месторождения Южного Приморья // Вестн. ДВО. 2009. № 6. С. 35-42.

6. Будищев А.Ф. Описание лесов южной части Приморской области // Леса Дальнего Востока глазами первопроходцев. СПб.: Изд-во Д.Ф. Львов, 2016. C. $25-384$.

7. Буссе Ф.Ф. Переселение крестьян морем в ЮжноУссурийский край в 1883-1893 годах с картою. СПб.: Тов. “Общественная Польза”, 1898. T. IV. $165 \mathrm{c}$.
8. Гариман Б.И., Мезенцева Л.И., Меновщикова Т.С., Попова Н.Ю., Соколов О.В. Условия формирования экстремально высокой водности рек Приморья в осенне-зимний период 2012 г. // Метеорология и гидрология. 2014. № 4. С. 77-92.

9. Государство Бохай (698-926 гг.) и племена Дальнего Востока России. М.: Наука, 1994. 219 с.

10. Карасев М.С., Гариман Б.И. Прогноз антропогенной динамики русловых процессов малых и средних рек Приморского края в условиях хозяйственного освоения их долин. Владивосток: Дальнаука, $2002.48 \mathrm{c}$.

11. Колесников Б.П. Растительность // Дальний Восток. М.: Изд-во АН СССР, 1961. С. 183-245.

12. Копотева Т.А., Купцова В.А. Пирогенный фактор на маревых болотах Приамурья // Вестн. СВНЦ ДВО РАН. 2011. № 3. С. 37-41.

13. Короткий А.М. Географические аспекты формирования субфоссильных спорово-пыльцевых комплексов (юг Дальнего Востока). Владивосток: Дальнаука, 2002. $271 \mathrm{c}$.

14. Короткий А.М., Гребенникова Т.А., Пушкарь В.С., Разжигаева Н.Г., Волков В.Г., Ганзей Л.А., Мохова Л.М., Базарова В.Б., Макарова Т.Р. Климатические смены на территории юга Дальнего Востока в позднем плейстоцене-голоцене // Вестн. ДВО PAH. 1997. № 3. C. 121-143.

15. Короткий А.М. Гребенникова Т.А., Караулова Л.П., Белянина Н.И. Озерные трансгрессии в позднекайнозойской Уссури-Ханкайской депрессии (Приморье) // Тихоокеан. геол. 2007. Т. 26. № 4. С. 53-68.

16. Крестов П.В., Верхолат В.П. Редкие растительные сообщества Приморья и Приамурья. Владивосток: ДВО РАН, 2003. $200 \mathrm{c}$.

17. Крюков Н.A. Очерк сельского хозяйства в Приморской области. СПб: Тип. В. Безобразова и $\mathrm{K}^{\mathrm{o}}, 1893$. $170 \mathrm{c}$.

18. Кудрявиева Е.П., Базарова В.Б., Лящевская М.С., Мохова Л.М. Амброзия полынолистная: современное распространение, структура сообществ и присутствие в голоценовых отложениях Приморского края (юг Дальнего Востока России) // Комаровские чтения. 2018. T. LXVI. C. 125-146.

19. Меньщиков А. Материалы по обследованию крестьянских хозяйств Приморской области. Старожилы стодесятинники (описание селений). Т. 4. Саратов: Тип. губерн. правления, 1912. 575 с.

20. Михайлик Т.А., Тищенко П.Я., Колтунов А.М., Тищенко П.П., Швецова М.Г. Влияние реки Раздольной на экологическое состояние вод Амурского залива (Японское море) // Водные ресурсы. 2011. T. 38. № 4. C. 474-484.

21. Микишин Ю.А., Петренко Т.И., Попов А.Н., Орлова Л.А. Палеогеография озера Ханка в позднем голоцене // Науч. обозрение. 2007. № 2. С. 7-13.

22. Никулина Т.В. Сообщества диатомовых водорослей реки Раздольной (Приморье) // Чтения памяти В.Н. Леванидова. 2003. № 2. С. 254-262.

23. Павлюткин Б.И., Петренко Т.И. Стратиграфия палеоген-четвертичных отложений Приморья. Владивосток: Дальнаука, 2010. 164 с. 
24. Петренко Т.И., Микишин Ю.А., Белянина Н.И. Субфоссильные спорово-пыльцевые комплексы Приханкайской равнины Приморья // Естеств. и техн. науки. 2009. № 4. С. 162-171.

25. Разжигаева Н.Г., Ганзей Л.А., Мохова Л.М., Макарова Т.Р., Паничев А.М., Кудрявцева Е.П., Арсланов Х.А., Максимов Ф.Е., Старикова А.А. Развитие ландшафтов Шкотовского плато Сихотэ-Алиня в позднем голоцене // Изв. РАН. Сер. геогр. 2016. № 3. C. $65-80$.

26. Разжигаева Н.Г., Ганзей Л.А., Гребенникова Т.А., Копотева Т.А., Климин М.А., Паничев А.М., Кудрявиева Е.П., Арсланов Х.А., Максимов Ф.Е., Петров А.Ю. Летопись палеонаводнений в предгорьях СихотэАлиня за последние 2.2 тысячи лет // Изв. РАН. Сер. геогр. 2019. № 2. С. 85-99.
27. Резолюции и материалы 3-го Краевого совещания Земельных работников ДВ края: 21-30 ноября 1926 года. Хабаровск: Книжное Дело, 1927. 141 с.

28. Элбакидзе E.A. Масштабы голоценовой ингрессии Японского моря в Южном Приморье (по данным диатомового анализа) // Тихоокеан. геол. 2014. T. 33. № 2. C. 102-108.

29. Chen Y., Hind D.J.N. Heliantheae // Flora of China, Asteraceae. Beijing: Science Press, St. Louis: Missouri Botanical Garden Press, 2011. V. 20-21. P. 852-878.

30. Jia $W$. Transition from Foraging to Farming in Northeast China. (PhD thesis). Sydney: Univ. of Sydney, 2005. $256 \mathrm{c}$.

31. Stebich M., Rehfeld K., Schlütz F., Tarasov P.E., Liu J. Holocene vegetation and climate dynamic of NE China based on the pollen record from Sihailongwan Maar Lake // Quat. Sci. Rev. 2015. V. 124. P. 275-289.

\title{
Interaction of Natural and Anthropogenic Factors in Landscape Development of Razdolnaya River Basin, Primorye
}

\author{
N. G. Razzhigaeva1, \#, L. A. Ganzey1, T. A. Grebennikova ${ }^{1}$, T. V. Kornyushenko ${ }^{1}$, K. S. Ganzei ${ }^{1}$, \\ E. P. Kudryavtseva ${ }^{1}$, I. V. Gridasova ${ }^{2}$, N. A. Kluyev ${ }^{2}$, and S. D. Prokopets ${ }^{2}$ \\ ${ }^{1}$ Pacific Geographical Institute FEB RAS, Vladivostok, Russia \\ ${ }^{2}$ Institute of History, Archaeology and Ethnography FEB RAS, Vladivostok, Russia \\ \#e-mail:nadyar@tigdvo.ru,lab39@mail.ru
}

\begin{abstract}
Landscapes' development in the Razdolnaya River Basin in the Starorechensky hillfort vicinity was reconstructed. Fragmentary data for the middle Holocene phase ( $\sim 5.9$ cal. ka) were obtained, in detail the reconstruction was carried out for the last $2.5 \mathrm{cal}$. ka. The development of landscapes took place in contrasting climatic conditions, moisture changed the most strongly. Five stages of the valley development under different humidity were reconstructed. The sections include buried soil formed in the droughty period in the second half of the late Holocene. At this time, steppe sagebrush, mixed herbs grasslands and birch woodlands were widespread. Climate in the late 7th-10th centuries gradually became warmer and more humid. Decrease of the temperature, with high humidity in the Little Ice Age with a constant renewal of the substrate on the floodplain during floods, led to an increase in areas occupied by Betula ovalifolia communities. The role of Pinus densiflora and birches increased in the mountain forests. Correlation of paleogeographic events with regional data is carried out. The role of the anthropogenic factor in the development of landscapes during the settlement of the valley by the Bohai agriculturalists, the first settlers of the 19th-beginning of 20th centuries and the development of modern agro-complexes was analyzed.
\end{abstract}

Keywords: landscapes, climatic changes, paleofloods, athropogenic factors, middle-late Holocene, Bohai hillfort, first settlers, Razdolnaya River, Primorye

\section{REFERENCES}

1. Ablaev A.G., Vasil'ev I.V. Miotsenovaya kraskinskaya flora Primor'ya [Miocene Kraskino Flora of the Primorye]. Vladivostok: Dal'nauka Publ., 1998. 107 p.

2. Agroklimaticheskie resursy Primorskogo kraya [Agroclimatic Resources of the Primorye]. Leningrad: Gidrometeoizdat Publ., 1973. $148 \mathrm{p}$.

3. Bazarova V.B., Lyashchevskaya M.S., Makarova T.R., Orlova L.A. Environments of the middle-late Holocene sedimentation in the river flood-plains of the Prikhanka Plain (south Far East). Tikhookean. Geol., 2018, vol. 37, no. 1, pp. 94-105. (In Russ.).

4. Bolikhovskaya N.S., Voskresenskaya T.N., Muratova M.V. On stratigraphy and paleogeography of the Late Pleisto- cene and Holocene deposits of Primorye. In Geokhronologiya chetvertichnogo perioda [Quaternary Geochronology]. Moscow: Nauka Publ., 1980, pp. 254-258. (In Russ.).

5. Bugdaeva E.V., Markevich V.S. Plant feedstock of the Cretaceous unique coals of Lipovetsky coal field of the Southern Primorye. Vestn. DVO, 2009, no. 6, pp. 35-42. (In Russ.).

6. Budishchev A.F. Description of the forests in the southern part of Primorsky region. In: Lesa Dal'nego Vostoka glazami pervoprokhodtsev [Forest of Far East through the Eyes of Pioneers]. St. Petersburg: D.F. L'vov Publ., 2016, pp. 25-384. (In Russ.).

7. Busse F.F. Pereselenie krest'yan morem v Yuzhno-Ussuriiskii krai v 1883-1893 godakh s kartoyu [The Resettle- 
ment of Peasants by Sea to the Southern Part of the Ussuri Region in 1883-1893 With Map]. St. Petersburg: Obshchestv. Pol'za Publ., 1898, vol. IV. 165 p.

8. Gartsman B.I., Mezentseva L.I., Popova N.Y., Sokolov O.V., Menovshchikova T.S. Conditions of generation of extremely high water content of Primorye rivers in autumn-winter 2012. Russ. Meteorol. Hydrol., 2014, no. 4, pp. 77-92.

9. Gosudarstvo Bokhai (698-926 gg.) i plemena Dal'nego Vostoka Rossii [The State of Balhae (698-926) and the Tribes of the Far East of Russia]. Moscow: Nauka Publ., 1994. 219 p.

10. Karasev M.S., Gartsman B.I. Prognoz antropogennoi dinamiki ruslovykh protsessov malykh i srednikh rek Primorskogo kraya $v$ usloviyakh khozyaistvennogo osvoeniya $i k h$ dolin [Forecast of Anthropogenic Dynamics of Channel Processes of Small and Medium-sized Rivers in Primorsky Krai in Conditions of Economic Development of their Valleys]. Vladivostok: Dal'nauka Publ., 2002. 48 p.

11. Kolesnikov B.P. Rastitel'nost'. In Dal'nii Vostok [Far East]. Moscow: Izd-vo USSR Academy of Science, 1961, pp. 183-245.

12. Kopoteva T.A., Kuptsova V.A. Fire in waterlogged open larch forests in the Amur River area. Vestn. SVNTS DVO $R A N$, 2011, no. 3, pp. 37-41. (In Russ.).

13. Korotkii A.M. Geograficheskie aspekty formirovaniya subfossil'nykh sporovo-pyl'tsevykh kompleksov (yug Dal'nego Vostoka) [Geographical Aspects of the Formation of Subfossil Pollen Complexes (the South of the Far East)]. Vladivostok: Dal'nauka Publ., 2002. 271 p.

14. Korotkii A.M., Grebennikova T.A., Pushkar' V.S., Razzhigaeva N.G., Volkov V.G., Ganzei L.A., Mokhova L.M., Bazarova V.B., Makarova T.R. Climatic changes in the territory of the South of the Far East at Late Pleistocene-Holocene. Vestn. DVO RAN, 1997, no. 3, pp. 121-143. (In Russ.).

15. Korotkii A.M., Grebennikova T.A., Karaulova L.P., Belyanina N.I. Lacustrine transgressions in the late Cenozoic Ussuri-Khanka depression (Primor'e). Russ. J. Pacific Geol., 2007, vol. 26, no. 4, pp. 53-68.

16. Krestov P.V., Verkholat V.P. Redkie rastitel'nye soobshchestva Primor'ya i Priamur'ya [Rare Plant Communities of Primorye and the Amur Region]. Vladivostok: Dal'nevost. Otd. Akad. Nauk, 2003. 200 p.

17. Kryukov N.A. Ocherk sel'skogo khozyaistva v Primorskoi oblasti [Essay on Agriculture in the Primorsky Region]. St. Petersburg: V. Bezobrazov i K Publ., 1893. 170 p.

18. Kudryavtseva E.P., Bazarova V.B., Lyashchevskaya M.C., Mokhova L.M. Common ragweed (Ambrosia artemisifolia): the present-day distribution and the presence in the Holocene deposits of Primorsky krai (south of the Russian Far East). Komarovskie Chteniya, 2018, vol. 66, pp. 125146. (In Russ.).

19. Men'shchikov A. Materialy po obsledovaniyu krest'yanskikh khozyaistv Primorskoi oblasti. Starozhily stodesyatinniki (opisanie selenii) [Materials on the Survey of the Peasant Farms in the Primorsky region. Oldtimers Stodesyatinniki (Description of Settlements)]. Saratov: Gubernskoe Pravlenie, 1912, vol. 4. 575 p.

20. Mikhailik T.A., Tishchenko P.Y., Koltunov A.M., Tishchenko P.P., Shvetsova M.G. The effect of Razdol'naya River on the environmental state of Amur Bay (the Sea of Japan). Water Resour., 2011, vol. 38, no. 4, pp. 474-484.

21. Mikishin Yu.A., Petrenko T.I., Orlova L.A. Paleogeography of the Khanka Lake in late Holocene. Nauchn. Obozrenie, 2007, no. 2, pp. 7-13. (In Russ.).

22. Nikulina T.V. Diatom communities of Razdolnaya River (Primorye territory). Chteniya Pamyati V.Ya. Levanidova, 2003, no. 2, pp. 254-262. (In Russ.).

23. Pavlyutkin B.I., Petrenko T.I. Stratigrafiya paleogenchetvertichnykh otlozhenii Primor'ya [Stratigraphy of Paleogene-Quaternary Deposits in Primorye]. Vladivostok: Dal'nauka Publ., 2010. 164 p.

24. Petrenko T.I. Mikishin Yu.A., Belyanina N.I. Sub-fossil pollen-spore complexes of Khanka Late flatland in Primorsky Krai, Russia. Estestv. Tech. Nauki., 2009, no. 4, pp. 162-171. (In Russ.).

25. Razzhigaeva N.G., Ganzei L.A., Mokhova L.M., Panichev A.M., Kudryavtseva E.P., Arslanov Kh.A., Maksimov F.E., Starikoiva A.A. The development of landscapes of the Shkotovo Plateau in the Late Holocene. Izv. Akad. Nauk, Ser. Geogr., 2016, no. 3, pp. 65-80. (In Russ.).

26. Razzhigaeva N.G., Ganzey L.A., Grebennikova T.A., Kopoteva T.A., Klimin M.A., Panichev A.M., Kudryavtseva E.P., Arslanov Kh.A., Maksimov F.E., Petrov A.Yu. Paleoflood records within Sikhote-Alin foothills during last $2.2 \mathrm{ka}$. Izv. Akad. Nauk, Ser. Geogr., 2019, no. 2, pp. 85-99. (In Russ.).

27. Resolutions and Materials of the 3rd Territorial Meeting of Land Workers of the Far East Region: November 21-30, 1926. Khabarovsk: Knizhnoe Delo Publ., 1927. 141 p. (In Russ.).

28. Elbakidze E.A. The extent of the Japan Sea Holocene ingression in Southern Primorye from the diatom analysis data. Tikhookean. Geol., 2014, vol. 33, no 2, pp. 102-108. (In Russ.).

29. Chen Y., Hind D.J.N. Heliantheae. In Flora of China, vol. 20-21: Asteraceae. Beijing: Sci. Press; St. Louis: Missouri Botanical Garden Press, 2011, vol. 20-21. pp. 852-878.

30. Jia W. Transition from Foraging to Farming in Northeast China. Sydney: Univ. of Sydney, 2005. 256 p.

31. Stebich M., Rehfeld K., Schluetz F., Tarasov P.E., Liu J., Mingram J. Holocene vegetation and climate dynamic of NE China based on the pollen record from $\mathrm{Si}$ hailongwan Maar Lake. Quat. Sci. Rev., 2015, vol. 124, pp. $275-289$. 